\title{
From the editor: COVID-19 and international business policy
}

\author{
Ari Van Assche ${ }^{1}$ and \\ Sarianna Lundan ${ }^{2}$ \\ ${ }^{1}$ HEC Montréal, 3000 chemin de la Côte-Sainte- \\ Catherine, Montreal, Québec H3T2A7, Canada; \\ ${ }^{2}$ Faculty of Business Studies and Economics, \\ University of Bremen, Enrique-Schmidt-Strasse 1, \\ 28359 Bremen, Germany
}

\section{Correspondence:}

A Van Assche, HEC Montréal, 3000 chemin de la Côte-Sainte-Catherine, Montreal, Québec H3T2A7, Canada

e-mail: ari.van-assche@hec.ca

\begin{abstract}
We introduce a special collection of papers on COVID-19 and international business policy that looks at the global policy challenge from different perspectives. The combination of confinement and protectionist measures including export bans, import tariffs and border closures that were introduced in response to the COVID-19 pandemic affect MNEs by increasing trade costs and amplifying the costs of communicating tacit knowledge. In this editorial, we draw specific attention to how these policies impact the heart of MNEs' activities - the knowledge-intensive intangibles. Physical distancing limits the face-to-face meetings that undergird the production of intangibles in large urban hotspots. At the same time, travel restrictions constrain MNEs' abilities to connect to and source knowledge from their foreign partners. Virtual conferencing has helped MNEs to cope with these challenges but it remains an imperfect substitute. A protracted public health crisis that would require limiting social interactions in the medium term might push MNEs to reconfigure their knowledge management strategies both locally and globally. Journal of International Business Policy (2020) 3, 273-279.

https://doi.org/ | 0.1057/s422/4-020-00065-7
\end{abstract}

Keywords: COVID-19; MNE; policy; intangibles; globalization

\section{INTRODUCTION}

In 2016, the Academy of International Business launched the ambitious project of adding a public policy journal to its line of publications - the Journal of International Business Policy. The rationale was that international business scholars have a deep knowledge about how the economic landscape influences firm behavior and vice versa, and this knowledge can be highly valuable in policy discussions (Lundan, 2018). The goal of the journal was therefore to promote a policy turn in international business research by pushing scholars to not only reflect on the implications of their research for managers, but also to investigate the societal implications of their studies (Van Assche, 2018).

The timing of the launch was auspicious as it coincided with a period where international business policy mounted to the forefront of public policy discussions. Populism had been rising on both sides of the Atlantic in the wake of the Great Recession of 2008-2009, which fed a wave of antitrade sentiment (Rodrik, 2018). Several government leaders jumped on the populist 


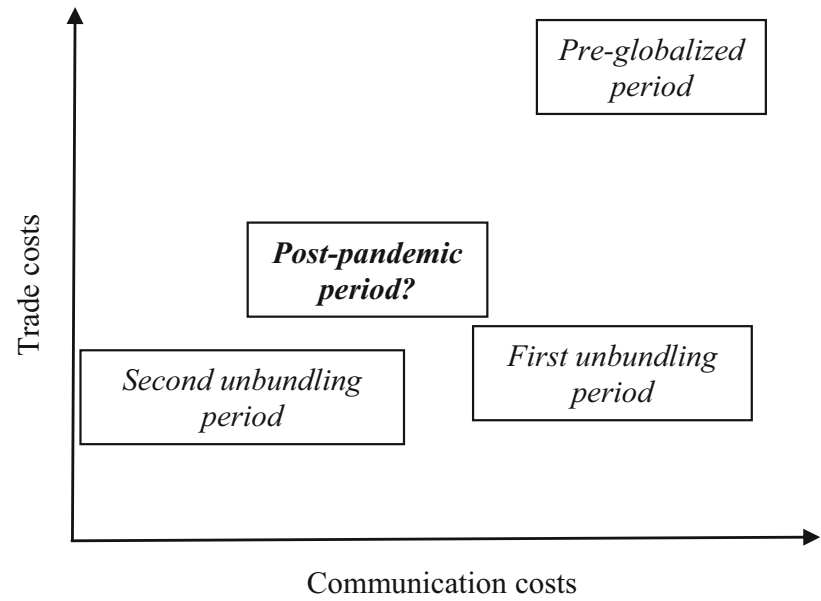

Figure 1 Trade and communication costs throughout history.

bandwagon by throwing their support behind export mercantilism (Evenett, 2019), renegotiating or leaving trade agreements, and initiating trade wars (Bown \& Irwin, 2019). International Business (IB) scholars were quick to seize the moment and have in ten JIBP journal issues put their own stamp on IB policy debates in an era of "slowbalization".

The 2020 "Great Lockdown" related to the COVID-19 pandemic is yet another policy challenge that can benefit from insights from IB scholarship. The instigator of the acute economic downturns across the globe is not the health crisis as such, but rather the policy response that has been remarkable in its suddenness, magnitude and synchronicity across countries. To halt the spread of the disease, governments have adopted extraordinary containment policies to flatten the epidemiological curve, that is, to slow the rate of new COVID-19 infections in order to ease the burden on local health facilities. When the epidemic initially hit, governments put a hard stop on economic activity by suspending operations of non-essential businesses, by closing international borders to nonessential traffic, and by implementing stringent stay-at-home orders. Once the initial outbreak was contained, countries have gradually loosened restrictions on those non-essential businesses where virus transmission can be more easily controlled. Lockdown exit strategies have varied substantially across countries and regions, but a common element is that physical distancing measures will need to remain in place until a vaccine or treatment becomes available.

Policy is also central to countries' efforts to cope with the resulting economic crisis. Governments have adopted a mix of fiscal, monetary and financial policies to avoid economic collapse related to the "hard stop" containment policies (Baldwin, 2020). As of April 2020, Japan and the United States have committed to fiscal stimulus packages that already exceed 10 percent of their annual gross domestic products (Elgin, Basbug, \& Yalaman, 2020).

International business policies have been part of the mix. Past experiences have shown that governments turn to protectionism during economic downturns (Evenett, 2019), and this time is no different. When the epidemic initially hit, several countries reacted to global shortfalls of personal protective equipment and testing kits by banning or limiting the export of medical equipment and medicines (Evenett, 2020). Once the attention turned from infection containment to economic recovery, several governments have switched to more traditional mercantilist policies by imposing import tariffs, putting into place "buy domestic" measures and adopting export subsidies (Bown, 2020). Most countries in the world have imposed partial or complete border closures to foreign nationals during the coronavirus outbreak (Chugh, 2020).

Businesses - including multinational enterprises (MNEs) - have been left scrambling trying to respond to the new policy reality. Much has been written about distilleries, textile companies and automotive firms that have ventured into the production of hand sanitizers, masks and ventilators (Fleming, 2020). Other studies have pointed out that firms are reorganizing their global value chains by reshoring production, diversifying their supplier base and adopting industry 4.0 technologies (Javorcik, 2020; Kilic \& Marin, 2020; Seric \& Winkler, 2020).

While these initial insights are valuable, it is fair to say that extant studies have only scratched the surface. Our understanding of the complex twoway interaction between COVID-19-related policies and IB remains murky and can benefit from fresh insights originating from IB scholarship. For this reason, we in early April contacted several leading scholars in IB and adjacent fields and asked them to provide their thoughts on the impact of the COVID-19 pandemic on international business both in the short and medium run. Our aim is to publish these articles in a JIBP special collection on COVID-19 and International Business Policy that will span the next two issues of the journal. 
In this editorial, we introduce the special collection by drawing the attention of JIBP readers to the impact of COVID-19-related policies that strike at the heart of MNEs - the knowledge-intensive intangibles - as their managers rush to cope with local physical distancing measures, non-essential travel restrictions and stringent immigration policies. At the end of the article, we also provide an overview of the first four papers that are included in the special collection.

\section{GLOBALIZATION AND THE ROLE OF INTANGIBLES}

In a recent book, Baldwin (2016) divided the history of globalization into three periods: the pre-globalization period (before 1820) when both trade and communication costs were high, the first unbundling period (1820-1990) when trade costs dropped but communication costs remained high, and the second unbundling period (1990-present) when both trade and communication costs became low (see Figure 1). ${ }^{1}$ He argued that each period has organized production and consumption in a different way, affecting trade and foreign investment flows.

The pre-globalized period was effectively a phase of autarky. High trade and communication costs isolated production and consumption to such a degree that the global economy was little more than a patchwork of local ecosystems that took care of themselves. While there was some international business (e.g., China's Silk Road trade), it had only a limited impact on a country's aggregate performance.

The arrival of steamships and railroads in the nineteenth century substantially lowered the cost of long-distance transportation. With cheaper international shipping, more consumers started buying faraway goods, allowing for the gradual separation of production and consumption. This first unbundling period led to a spurt in international business, but the high communication costs across borders confined production processes within countries.

Globalization accelerated again at the end of the twentieth century, when the ICT revolution slashed the cost of communicating codifiable information at a distance. This instigated globalization's second unbundling period, which involved the international fragmentation of production. Improvements in communication technology now made it feasible and profitable to coordinate production activities across different countries, allowing for the emergence of global value chains.
IB scholarship has brought to the table several refinements that have enriched this depiction of globalization. First, it has highlighted the central role that MNEs have played in driving change over the two unbundling periods. As MNE managers observed shifts in the costs and risks of doing business abroad, they reassessed how to compete, where to extend their geographical footprint and which activities to conduct within firm boundaries (Buckley \& Strange, 2015; Verbeke, Coeurderoy, \& Matt, 2018). It is MNEs' adoption of new forms of intra- and inter-organizational arrangements on the micro-level that instigated shifts in macro trade and investment flows.

Second, IB scholarship has emphasized that MNEs not only adapt the tangible parts of their activities - the production, trade and sale of physical goods - but also the intangibles which are at the heart of MNE operations. Intangibles are those claims to future benefits that do not have a physical or financial embodiment (Lev, 2001). Highly knowledge-intensive in nature, they include the intellectual property, brand equity and other economic competencies that provide MNEs the economic power to set product strategy, place orders, and take financial responsibility for the goods and services that their supply chains turn out (Sturgeon, 2009; Teece, 2018). The drop in communication costs during the second unbundling period has pushed MNEs to not only fragment production internationally but also to globalize the production of intangibles. A highly influential IB literature describes the complex global knowledge management strategies that MNEs adopt to transfer and exploit existing repositories of knowledge around the world and to engage in the exploration of new knowledge (Alcácer, Cantwell \& Piscitello, 2016; Cantwell, 1989; Kogut \& Zander, 1993).

One of the reasons these knowledge management strategies are complex is that MNEs need to consider the paradoxical geography of knowledge creation which is both concentrated in few local hotspots and increasingly global (Lorenzen, Mudambi \& Schotter, 2020). The tacit nature of much of the knowledge that is embedded in intangibles implies that there are significant agglomeration economies in the production of intangibles (Glaeser \& Gottlieb, 2009). One reason for this is that complex forms of knowledge are difficult to communicate over distance and require direct and repeated face-to-face contact for their exchange (Storper \& Venables, 2004; D’Este, Guy, \& Iammarino, 2013). For firms, co-locating with 
similar and related companies thus can boost collective learning processes through frequent opportunities for formal and informal knowledge exchanges. Several recent studies provide strong evidence that the production of intangibles concentrates disproportionately in a few urban hotspots (Crescenzi et al., 2019; Moretti, 2019; Balland et al., 2020).

A complementary feature is that lead firms have developed sophisticated strategies to allow teams of people in different global cities to collaborate in the production of intangibles. Many lead firms nowadays deliberately establish linkages to other global knowledge hotspots to tap into pockets of complementary knowledge and resources that are unavailable or more expensive locally (Bathelt, Malmberg, \& Maskell, 2004). They do so by setting up intrafirm linkages to competence-creating subsidiaries or by developing inter-firm partnerships (Bathelt, Cantwell, \& Mudambi, 2018). Once new knowledge combinations are created, these can then be transferred to the home country or other locations to enhance the parent firm's innovation performance (Cano-Kollmann et al., 2016). Regardless of the governance structure adopted, and the knowledge exchanges facilitated by ICT, the mobility of key personnel is a key factor that keeps these "pipelines" open.

\section{INTANGIBLES IN A WORLD WITH COVID-19}

Several scholars have voiced their concern that the current COVID-19 pandemic may have a lasting impact on globalization in general and more specifically on the ways in which MNEs configure their cross-border activities (Altman, 2020; Irwin, 2020; Kobrin, in this issue). The combination of COVID-19-related confinement and protectionist measures is effectively a policy mix that affects MNEs by (1) increasing trade costs and (2) amplifying the costs of communicating tacit knowledge (see Figure 1).

The increase in trade costs reflects in part the struggle to adapt the international transportation system to the COVID-19-related policy measures. The unprecedented grounding of passenger planes has disrupted air transport since a significant portion of air cargo is transported in the hold of passenger planes (Van Assche, 2020). Many ports' restrictions on vessels and crew changes have led to similar disruptions in sea freight (Heiland \& Ulltveit-Moe, 2020). Protectionist measures have added to these trade cost increases. With governments trying to limit the health and economic impact on their people, some 75 countries have restricted their exports of hundreds of products, ranging from antibiotics to cotton face masks and medical ventilators (Evenett, 2020). The United States has reignited its trade war with China. Japan has promised subsidies to Japanese companies that are willing to reshore production from China to Japan.

The policy response to COVID-19 has also amplified the costs of communicating tacit knowledge. Locally, the physical distancing rules have severely limited both the planned and unplanned face-toface meetings that undergird the buzz of local innovation ecosystems. Internationally, the closing of borders to non-essential travel and limits to immigration have limited firms' abilities to collaborate and exchange tacit knowledge with their foreign partners.

The availability of digital infrastructure has allowed firms to limit the scope of disruptions related to the reduction in face-to-face interactions and may well have a permanent impact on global knowledge management practices in the post-pandemic period. For many office workers, telework and virtual conferencing have become the new norm. Some companies such as Twitter have even announced that staff can continue to work from home permanently. Despite vast improvements in virtual conferencing capabilities, they nonetheless remain imperfect substitutes to face-to-face meetings.

The effect of COVID-19 on the development of intangibles will depend on both the duration of the health crisis and the extent to which the economy can return to normal once the pandemic itself is behind us. A relatively short crisis with a swift relaxing of physical distancing rules, an opening up of international borders and elimination of protectionist measures will likely lead to the return of established practices. A protracted public health pandemic, then again, that continues to limit social interactions in the medium term and potentially leads to a global descent into protectionism will require firms to reconfigure their business models on both the tangible and intangible side.

\section{CONCLUSION: CONTRIBUTIONS IN THE SPECIAL COLLECTION}

In this editorial we have highlighted just one topic area where international business scholarship can be instrumental in understanding the link between 
COVID-19 and eventual economic recovery. The JIBP special collection on COVID-19 and International Business Policy includes several other original papers, including four that are published in this issue. We hope that these papers stimulate members of the IB community and beyond to engage in conversations about the ongoing policy challenges facing the global economy, and to place these issues on their research agenda alongside other ongoing sources of disruption such as climate change and rising inequality within and between countries.

The collection opens with Steve Kobrin's thoughts on the impact of COVID-19 on globalization. He argues that the pandemic has for the second time in little more than a decade laid bare the very real social, political and economic dangers of high specialization and connectedness between markets. After acting as a potent vehicle for the transmission of a global financial crisis during the Great Recession of 2008-2009, the globalized system has during the COVID-19 pandemic of 2020 acted as a virulent medium for the spread of a health calamity that continues to wreak havoc across the globe. According to Kobrin, these events further undermine the longstanding belief that globalization is an indicator of progress and they have reinforced fears of "the other" that are all too easy to exploit for political gain. He points out three major changes that need to occur to restore a positive view of globalization: restoring the balance between sovereignty and integration; making globalization more inclusive; and insuring some degree of resilience in global supply chains. However, Kobrin is skeptical that the current geopolitical climate is conducive to these changes.

In a second paper, Gary Gereffi digs deeper into one of the "choke points" that have been uncovered by the COVID-19 pandemic, namely the global shortages of medical supplies in the early months of the health crisis. He questions the oftenheard assertion that these shortages were due to structural flaws in medical equipment supply chains and conducts a detailed case study of the face mask value chain in the United States to evaluate this claim. According to Gereffi, the shortage of masks in this case was much more a policy failure than a market failure. While just-intime production techniques could make supply chains fragile in times of crisis, they did not stop the American company $3 \mathrm{M}$ from quadrupling its
U.S. supply of N95 masks from just over 20 million in January to 95 million per month in May. Rather, the critical bottleneck appeared to be the limited government stockpiling of N95 masks before the crisis and the regulatory constraints that in early 2020 prevented $3 \mathrm{M}$ and its competitors from scaling up local production.

In a third paper, Rajneesh Narula turns to the other side of these global value chains and focuses on the impact of the COVID-19 pandemic on the informal economy in developing countries. According to Narula, informal workers and enterprises have been especially vulnerable to the pandemicinduced economic shock. For decades, global value chains have used the informal sector in developing countries as a valve that takes on extra tasks during periods of peak demand. Unfortunately, the reverse side of the coin is that informal workers and firms have also been the first to be cut from the roster when the valve is turned off during economic downturns. Often living from hand to mouth, and with limited government rescue packages to help them, COVID-19 has thus condemned millions of workers in the informal economy to poverty. Narula nonetheless sees a (faint) silver lining: The severity of the economic shock and the precariousness of the informal sector may finally convince governments to actively engage with informal actors without pushing for their formalization, for example by placing them on par with formal firms when implementing industrial policy.

In a fourth paper, Peter Buckley reflects on the impact of COVID-19 for China's highly ambitious infrastructure-building Belt Road Initiative (BRI) that spans a large number of developing economies across Asia. Even before the current pandemic, there were concerns in several BRI countries that the high costs of the investment projects were leading to unprecedented levels of debt. Buckley points out that these apprehensions have only increased in the wake of the COVID-19 pandemic as governments face severe revenue shortfalls, as they embrace new budgetary priorities in light of the health crisis, and as China faces growing geopolitical tensions with the United States. He nonetheless suggests that China's need to address its own domestic overcapacity combined with the amorphous nature of BRI provides the Chinese government with the means to flexibly rethink its BRI strategy in the face of the COVID-19-related setbacks. 


\section{NOTES}

${ }^{1}$ This classification is similar to that presented by Jones (2005) with the exception that the (policy-

\section{REFERENCES}

Alcácer, J., Cantwell, J., \& Piscitello, L. 2016. Internationalization in the information age: A new era for places, firms, and international business networks? Journal of International Business Studies, 47(5): 499-512.

Altman, S. A. 2020. Will COVID-19 have a lasting impact on globalization? Harvard Business Review, May 20: https://hbr. org/2020/05/will-covid-19-have-a-lasting-impact-onglobalization.

Baldwin, R. 2016. The great convergence. Cambridge, MA: Harvard University Press.

Baldwin, R. 2020. The supply side matters: guns versus butter, COVID-style. VoxEU.org, March 22: https://voxeu.org/article/ supply-side-matters-guns-versus-butter-covid-style.

Balland, P. A., Jara-Figueroa, C., Petralia, S. G., Steijn, M. P., Rigby, D. L., \& Hidalgo, C. A. 2020. Complex economic activities concentrate in large cities. Nature Human Behaviour, 4(3): 248-254.

Bathelt, H., Malmberg, A., \& Maskell, P. 2004. Clusters and knowledge: Local buzz, global pipelines and the process of knowledge creation. Progress in Human Geography, 28(1): 3156.

Bathelt, H., Cantwell, J. A., \& Mudambi, R. 2018. Overcoming frictions in transnational knowledge flows: Challenges of connecting, sense-making and integrating. Journal of Economic Geography, 18(5): 1001-1022.

Bown, C. 2020. COVID-19 could bring down the trading system. Foreign Affairs, April 28: https://www.foreignaffairs. com/articles/united-states/2020-04-28/covid-19-could-bringdown-trading-system.

Bown, C. P., \& Irwin, D. A. 2019. Trump's assault on the global trading system: And why decoupling from China will change everything. Foreign Affairs, 98: 125.

Buckley, P. J., \& Strange, R. 2015. The governance of the global factory: Location and control of world economic activity. Academy of Management Perspectives, 29: 237-249.

Cano-Kollmann, M., Cantwell, J., Hannigan, T. J., Mudambi, R., \& Song, J. 2016. Knowledge connectivity: An agenda for innovation research in international business. Journal of International Business Studies, 47(3): 255-262.

Cantwell, J. A. 1989. Technological innovation and multinational corporations. Oxford: Basil Blackwell.

Chugh, A. 2020. Will COVID-19 change how we think about migration and migrant workers? World Economic Forum, May 22: https://www.weforum.org/agenda/2020/05/covid-19coronavirus-migration-migrant-workers-immigration-policyhealth-securitization-risk-travel-bubbles/.

Crescenzi, R., lammarino, S., loramashvili, C., Rodriguez-Pose, A., \& Storper, M. 2019. The geography of innovation: local hotspots and global innovation networks. WIPO Economic Research Working Paper No. 57.

D'Este, P., Guy, F., \& lammarino, S. 2013. Shaping the formation of university-industry research collaborations: What type of proximity does really matter? Journal of Economic Geography, 13(4): 537-558.

Elgin, C., Basbug, G., \& Yalaman, A. 2020. Economic policy responses to a pandemic: Developing the COVID-19 economic stimulus index. VoxEU.org, May 7: https://voxeu.org/ article/economic-policy-responses-pandemic-covid-19economic-stimulus-index.

Evenett, S. J. 2019. Protectionism, state discrimination, and international business since the onset of the Global Financial Crisis. Journal of International Business Policy, 2(1): 9-36. induced) collapse of international trade in the interwar years is not considered separately.

Evenett, S. J. 2020. Sicken thy neighbour: The initial trade policy response to COVID-19. The World Economy, 43(4): 828-839.

Fleming, S. 2020. How big business is joining the fight against COVID-19. World Economic Forum, March 23: https://www. weforum.org/agenda/2020/03/big-business-joining-fightagainst-coronavirus/.

Glaeser, E. L., \& Gottlieb, J. D. 2009. The wealth of cities: Agglomeration economies and spatial equilibrium in the United States. Journal of Economic Literature, 47(4): 983-1028.

Heiland, I., \& Ulltveit-Moe, K. 2020. An unintended crisis: COVID-19 restrictions hit sea transportation. VoxEU.org, May 17: https://voxeu.org/article/covid-19-restrictions-hit-seatransportation.

Irwin, D. 2020. The pandemic adds momentum to the deglobalization trend. VoxEU.org, May 5: https://voxeu.org/article/ pandemic-adds-momentum-deglobalisation-trend.

Javorcik, B. 2020. The Greater Trade Collapse of 2020: Learnings from the 2008-09 Great Trade Collapse. VoxEU.org, April 7: https://voxeu.org/article/greater-trade-collapse-2020.

Jones, G. 2005. Multinationals and global capitalism: From the nineteenth to the twenty first century. New York: Oxford University Press.

Kilic, K., \& Marin, D. 2020. How COVID-19 is transforming the world economy. VoxEU.org, May 10: https://voxeu.org/ article/how-covid-19-transforming-world-economy.

Kobrin, S. 2020. How globalization became a thing that goes bump into the night. Journal of International Business Policy. https://doi.org/10.1057/s42214-020-00060-y.

Kogut, B., \& Zander, U. 1993. Knowledge of the firm and the evolutionary theory of the multinational corporation. Journal of International Business Studies, 24(4): 625-645.

Lev, B. 2001. Intangibles: Management, measurement, and reporting. Washington, DC: Brookings Institution Press.

Lorenzen, M., Mudambi, R., \& Schotter, A. 2020. International connectedness and local disconnectedness: MNE strategy, city-regions and disruption. Journal of International Business Studies. https://doi.org/10.1057/s41267-020-00339-5.

Lundan, S. M. 2018. From the editor: Engaging international business scholars with public policy issues. Journal of International Business Policy, 1(1): 1-11.

Moretti, E. 2019. The effect of high-tech clusters on the productivity of top inventors (p. w26270). No: National Bureau of Economic Research.

Rodrik, D. 2018. Populism and the economics of globalization. Journal of International Business Policy, 1(1): 12-33.

Seric, A., \& Winkler, D. 2020. COVID-19 could spur automation and reverse globalisation - to some extent. VoxEU.org, April 28: https://voxeu.org/article/covid-19-could-spurautomation-and-reverse-globalisation-some-extent.

Storper, M., \& Venables, A. J. 2004. Buzz: Face-to-face contact and the urban economy. Journal of Economic Geography, 4(4): $351-370$.

Sturgeon, T. J. (2009). From commodity chains to value chains: Interdisciplinary theory building in an age of globalization. In J. Bair (Ed.), Frontiersof commodity chain research (pp. 110135). Stanford, California: Stanford University Press.

Teece, D. 2018. Business models and dynamic capabilities. Long Range Planning, 51(1): 40-49.

Van Assche, A. 2018. From the editor: Steering a policy turn in international business-opportunities and challenges. Journal of International Business Policy, 1(3): 117-127.

Van Assche, A. 2020. Trade is among the casualties in the COVID-19 pandemic. Policy Options, March 27: https:// 
policyoptions.irpp.org/magazines/march-2020/trade-isamong-the-casualties-in-the-covid-19-pandemic/.

Verbeke, A., Coeurderoy, R., \& Matt, T. 2018. The future of international business research on corporate globalization that never was.... Journal of International Business Studies, 49(9): 1101-1112.

\section{ABOUT THE AUTHORS}

Ari Van Assche is Professor of International Business at HEC Montréal and deputy editor of the Journal of International Business Policy. His research focuses on the organization of global value chains and their implications for international trade, industrial clusters and public policy.

Sarianna Lundan holds the Chair in International Management and Governance at the University of Bremen and she is the Editor-in-Chief of the Journal of International Business Policy. Her research focuses on the impact of MNEs on the home and host countries and the co-evolution of firms and institutions. She is a Fellow of the Academy of International Business (AIB) and the European International Business Academy (EIBA).

Publisher's Note Springer Nature remains neutral with regard to jurisdictional claims in published maps and institutional affiliations. 